\title{
Genetic divergence between Pseudoplatystoma corruscans and Pseudoplatystoma reticulatum (Siluriformes: Pimelodidae) in the Paraná River Basin
}

\author{
Bignotto, TS. ${ }^{\mathrm{a}, \mathrm{d}}$, Prioli, AJ. ${ }^{\mathrm{a}, \mathrm{b} *}$, Prioli, SMAP. ${ }^{\mathrm{a}, \mathrm{b}}$, Maniglia, TC. ${ }^{\mathrm{b}, \mathrm{c}}$, Boni, TA. ${ }^{\mathrm{b}}$, Lucio, $_{\text {LC. }}{ }^{\mathrm{b}, \mathrm{c}}$, \\ Gomes, VN. ${ }^{\mathrm{b}, \mathrm{c}}$, Prioli, RA. ${ }^{\mathrm{b}}$, Oliveira, AV. ${ }^{\mathrm{b}}$, Júlio-Junior, $H F^{\mathrm{b}, \mathrm{c}}$ and Prioli, LM. ${ }^{\mathrm{b}}$ \\ aDepartamento de Biologia Celular e Genética, \\ Universidade Estadual de Maringá - UEM

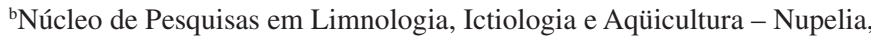 \\ Universidade Estadual de Maringá - UEM, \\ Av. Colombo 5790, Bloco G-90, 87020-900 Maringá, PR, Brasil \\ 'Programa de Pós-graduação em Ecologia de Ambientes Aquáticos Continentais, \\ Universidade Estadual de Maringá - UEM \\ dPrograma de Pós-graduação em Genética e Melhoramento, \\ Universidade Estadual de Maringá - UEM \\ *e-mail: ajprioli@nupelia.uem.br
}

Received November 27, 2008 - Accepted March 7, 2009 - Distributed June 30, 2009

(With 5 figures)

\begin{abstract}
Pseudoplatystoma corruscans (Spix and Agassiz, 1829) and Pseudoplatystoma reticulatum (Eingenmann and Eigenmann, 1889) are large migratory catfishes of high biological importance and great commercial value in South America. Because fertile crossbreeds can be artificially produced in hatcheries, a high genetic proximity between these two Pimelodidae species is conceivable. Possible escape of crossbred specimens from pisciculture stations is a serious environmental concern. Despite their importance, knowledge of $P$. corruscans and $P$. reticulatum biology, ecology, population diversity and genetics is limited. In the present work, the genetic divergence between $P$. corruscans and $P$. reticulatum populations from the Paraná River Basin was analyzed on the basis of polymorphisms in ISSR fragments and in the hypervariable sequence of the mitochondrial DNA (mtDNA) control region. Estimates of intraspecific haplotype $(h>0.5)$ and nucleotide diversities $(\pi<0.01)$ indicate that $P$. corruscans and P. reticulatum have survived a historical population decline, followed by a demographic expansion. The interspecific polymorphisms within the mtDNA control region and ISSR fragments were suitable as diagnostic molecular markers and could be used to discriminate the two species. A unique Pseudoplatystoma specimen, captured in the Upper Paraná River Floodplain, was identified by these DNA diagnostic markers as a hybrid $P$. reticulatum $\times P$. corruscans, which possibly escaped from pisciculture. The integrity of the natural population of $P$. corruscans in the Upper Paraná River is at risk of genetic introgression or homogenization due to the presence of hybrids and the transposition of P. reticulatum upstream through the Canal da Piracema at Itaipu Dam. Data presented herein improve the understanding of the genetic relatedness between $P$. corruscans and $P$. reticulatum and represent potential tools for future programs of conservation and surveillance of genetic introgression events and the genetic integrity of these populations.
\end{abstract}

Keywords: Pseudoplatystoma, interspecific hybrid, D-loop, ISSR, Upper Paraná River.

\section{Divergência genética entre Pseudoplatystoma corruscans e Pseudoplatystoma reticulatum (Pisces; Siluriformes) da Bacia do Rio Paraná}

\footnotetext{
Resumo

Pseudoplatystoma corruscans Spix e Agassiz, 1829 e Pseudoplatystoma reticulatum Eigenmann e Eigenmann, 1889 são peixes migratórios de grande porte, com alta importância biológica e elevado valor comercial na América do Sul. Híbridos férteis são obtidos em cativeiro e, portanto, é esperada alta proximidade genética entre essas duas espécies de Pimelodidae. Escapes de espécimes híbridos a partir de estações de piscicultura representam um sério problema ambiental. Apesar da sua importância, conhecimentos sobre a biologia, ecologia, diversidade de populações e genética de $P$. corruscans e $P$. reticulatum são escassos. No presente trabalho, foi avaliada a divergência genética entre P. corruscans e P. reticulatum da Bacia do Rio Paraná, com base em fragmentos ISSR e na sequiência $D$-loop do
} 
DNA mitocondrial (mtDNA). As estimativas das diversidades intra-específicas haplotípica $(h>0,5)$ e nucleotídica $(\pi<0,01)$ evidenciaram que $P$. corruscans e $P$. reticulatum sobreviveram a um declínio populacional histórico, seguido de expansão demográfica. Os polimorfismos interespecíficos no mtDNA e nos fragmentos ISSR foram eficientes para diagnósticos e discriminaram as duas espécies. Um espécime de Pseudoplatystoma capturado na planície de inundação do Alto Rio Paraná foi identificado com esses marcadores moleculares como híbrido P. reticulatum $\times$ $P$. corruscans, que possivelmente escapou de psicicultura. A integridade da população de $P$. corruscans no Alto Rio Paraná está ameaçada, por introgressão ou homogeneização genética, pela presença de híbridos e pela transposição para montante de $P$. reticulatum através do Canal da Piracema em Itaipu. Os dados apresentados constituem um avanço na compreensão do parentesco entre $P$. corruscans e $P$. reticulatum e representam ferramentas em potencial para programas de conservação biológica, incluindo o monitoramento de introgressão e de integridade genética das populações.

Palavras-chave: Pseudoplatystoma, híbrido interespecífico, D-loop, ISSR, Alto Rio Paraná.

\section{Introduction}

The Pimelodidae catfishes Pseudoplatystoma corruscans (Spix and Agassiz, 1829), popularly known as 'pintado' or 'spotted sorubim', and Pseudoplatystoma reticulatum (Eigenmann and Eigenmann, 1889), known as 'cachara' or 'barred sorubim', are among the largest fishes in the main South American hydrographic basins. These abundant migratory fishes are important predators in these basins. Buitrago-Suárez and Burr (2007) recognized that the Pseudoplatystoma genus contains eight species. P. reticulatum, formerly P. fasciatum, is distributed throughout the Amazon and Paraná River Basins, while $P$. fasciatum is restricted to the Guyana region.

In nature, $P$. corruscans and $P$. reticulatum coexist only in part of the Paraná hydrographic basin, at the Middle Paraná River Basin, including the Paraguay River sub-basin (Buitrago-Suárez and Burr, 2007). The genetic proximity between $P$. corruscans and $P$. reticulatum has been inferred primarily based on their known ability to generate fertile hybrids upon the induction of interspecific crosses in hatcheries. Because of their large size and remarkably appreciated meat quality, both species are of high commercial value and are greatly appreciated for sport fishery. Despite their biological and fishery importance, knowledge of the biology, ecology and genetics of $P$. corruscans and $P$. reticulatum is still quite limited.

The $P$. corruscans and $P$. reticulatum catfishes have been increasingly threatened by rapid and drastic environmental changes. Consequently, there has been a severe decline in the reproduction and capture of both species (Petrere-Jr. et al., 2002). Hence, there is now a greater interest in their reproduction in hatcheries for commercial purposes (Sato et al., 1997). Moreover, interspecific hybrids between $P$. corruscans and $P$. reticulatum can be generated in hatcheries, and eventual escapes into a natural environment are likely to occur. Particularly in the case of fertile hybrids, such escapes can represent a serious threat to the genetic integrity of local populations due to the risk of backcrossing and gene introgression (Avise, 2004). In the Upper Paraná River Basin, where the $P$. reticulatum species does not naturally exist, escapes of $P$. reticulatum $\times P$. corruscans fertile hybrids could be particularly menacing. Furthermore, the building of dams in the Upper Paraná River Basin has rapidly isolated fish populations, and this is especially threatening to the dispersion of species that undergo long-distance reproduction migrations, such as $P$. corruscans. Therefore, monitoring of populations is becoming essential for preserving both Pseudoplatystoma species.

Molecular markers are fundamental for monitoring population genetic variability and for the surveillance of populations that are potentially at risk of losing their genetic integrity. In addition, they represent an important tool for studies of the genetic diversity and evolution of fishes. The availability of nuclear and mitochondrial DNA markers that are easily accessible and suitable for characterizing and discriminating $P$. corruscans and $P$. reticulatum is a fundamental requirement in the study and supervision of these populations. Moreover, these molecular markers could enable a better understanding of the genetic relatedness of these two species.

ISSR (Inter Simple Sequence Repeats) fingerprinting is a feasible molecular tool that does not require previous sequencing knowledge (Reddy et al., 2002). This technique uses a single primer containing the repetitive sequence of a microsatellite. The amplified DNA segment includes the nucleotide sequence situated between two microsatellites blocks, yielding a multilocus marker system useful for genetic diversity analysis (Maltagliati et al., 2006). The variable lengths of these amplified DNA sequences allow for the identification of differences between closely related species, although they reveal little information about the genetic variability within a single species (Reddy et al., 2002). In addition, the hypervariable domain of the control region (D-loop) in the mitochondrial genome has been a sequence of choice for taxonomic and genetic studies of populations and closely related vertebrates species, including fishes (Aboim et al., 2005; Oliveira et al., 2006). These nuclear and mitochondrial markers would be useful in evaluating genetic divergence between $P$. corruscans and $P$. reticulatum and could provide diagnostic loci for identifying first or advanced generations of interspecific hybrids.

The objective of the present work was to analyze the genetic divergence between $P$. corruscans and P. reticulatum populations from the Paraná River Basin and to identify diagnostic DNA markers suitable for 
the discrimination of these two species. This proposed characterization could improve the understanding of the genetic relatedness between these Pseudoplatystoma species and may provide additional tools for future evaluations of hybridization and genetic introgression as well as for monitoring the genetic integrity of populations.

\section{Materials and Methods}

\subsection{Fish sampling and DNA extraction}

As shown in Figure 1, specimens of Pseudoplatystoma corruscans were sampled in the northern Paraguay River sub-basin (location 1) and in the floodplain of the Upper Paraná River Basin (location 2). Pseudoplatystoma reticulatum was sampled only in the northern Paraguay River sub-basin, as it does not exist in the Upper Paraná. In this study, a unique specimen of Pseudoplatystoma (2-PHybr1), which was characterized by concomitant patterns of spots and striped skin color, was also included. The 2-PHybr1 specimen was captured in nature, at the floodplain of the Upper Paraná River. Because of its morphological traits, which were intermediate between both species, the 2-PHybr1 specimen was hypothesized to be an interspecific hybrid of $P$. reticulatum and $P$. corruscans. Fish specimens were captured with gillnets. Tissues were obtained from the adipose fins of the $P$. reticulatum and $P$. corruscans samples and from the muscles of the 2-PHybr1 specimen. Tissues were fixed in ethanol and stored at $-20^{\circ} \mathrm{C}$. Samples $(\sim 100 \mathrm{mg})$ were then macerated in liquid nitrogen and total DNA was extracted according to Whitmore et al. (1992), with few modifications (Prioli et al., 2002).

\subsection{Amplification and analysis of ISSR loci}

DNA fragments were amplified by PCR of total DNA samples using the primers (GGAC) $)_{3}$, (GGAC) ${ }_{3} \mathrm{C}$ and (GGAC) $)_{4}$ as previously described (Gupta et al., 1994), with few modifications. The ISSR analysis included 19 specimens of $P$. corruscans, 18 specimens of $P$. reticulatum (both from the northern Paraguay River sub-basin) and the 2-PHybr-1 specimen. The PCR reaction mix consisted of Tris- $\mathrm{KCl}(20 \mathrm{mM}$ Tris- $\mathrm{HCl}, \mathrm{pH} 8.4$ and $50 \mathrm{mM} \mathrm{KCl}$ ), $1.5 \mathrm{mM} \mathrm{MgCl}, 2.5 \mu \mathrm{M}$ of each primer, $0.1 \mathrm{mM}$ of each dNTP, 1.0 U Taq DNA polymerase (Invitrogen), $15 \mathrm{ng}$ DNA and sterilized water to a total volume of $13 \mu \mathrm{L}$. PCR amplification was performed in 5 cycles of $94{ }^{\circ} \mathrm{C}$ for 45 seconds, $51{ }^{\circ} \mathrm{C}$ for 1 minute and $72{ }^{\circ} \mathrm{C}$ for 1 minute, immediately followed by 30 cycles of $94{ }^{\circ} \mathrm{C}$ for 45 seconds, $50{ }^{\circ} \mathrm{C}$ for 1 minute, $72{ }^{\circ} \mathrm{C}$ for 1 minute. PCR amplification reproducibility was tested in at least two independent reactions. In addition, one to two samples of PCR products, previously amplified and analyzed with the same primer, were included in each agarose gel. A sample consisting of the PCR reaction mix without DNA was included as a negative control in each experiment. PCR amplified DNA fragments were separated by electrophoresis in an agarose gel (1.4\%), which

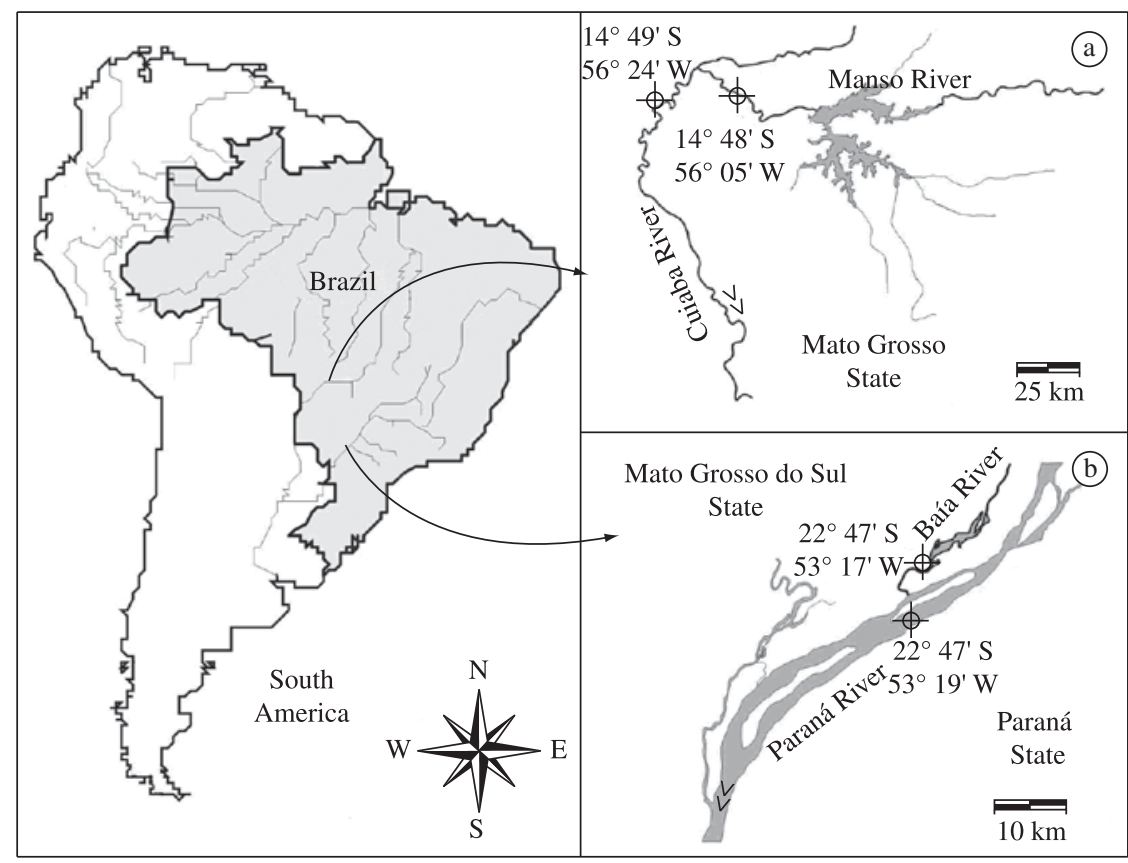

Figure 1. Map displaying the sampling locations from which Pseudoplatystoma specimens were obtained. At Location a, situated in the northern Paraguay River Basin, P. corruscans and P. reticulatum were sampled in the Manso and Cuiabá Rivers. At Location b, situated in the floodplain of the Paraná River Basin, P. corruscans was sampled in the Baía River and the 2-PHybr1 specimen was captured in the Paraná River. 
was stained with ethidium bromide $(20 \mu \mathrm{g} / 100 \mathrm{~mL})$, at $5 \mathrm{~V} . \mathrm{cm}^{-1}$ for 4-5 hours. Electrophoresis profiles were visualized with UV irradiation and photographed with a Kodak EDAS-290. Analysis of ISSR fragment polymorphisms was based on the presence or absence of accurate steady DNA bands on the agarose gel. Specimens were compared within and among populations. The Nei and Li genetic similarity was estimated using NTSYS 1.7 and was utilized in both neighbor-joining clustering and principal coordinates analysis. Indexes of molecular diversity $F_{\mathrm{ST}}$ were estimated based on the average genetic diversity over all haplotype loci using Arlequin v. 3.11.

\subsection{Sequencing and analysis of mitochondrial DNA}

A fragment of mtDNA, approximately 460 base pairs (bp) in length, was PCR amplified from DNA samples of seven $P$. corruscans specimens from the Paraguay River sub-basin and 15 specimens from the Upper Paraná River Basin, of seven $P$. reticulatum specimens, and of the PHybr-1 specimen. For PCR, the D-loop L 5'-AGAGCGTCGGTCTTGTAAACC-3' and H16498 5'-CCTGAAGTAGGAACCAGATG-3' primers were used. The PCR reactions were performed according to Prioli et al. (2002) and DNA sequencing reactions were performed according to Oliveira et al. (2006). For each specimen, the fragment was amplified in two independent reactions and then bi-directionally sequenced. Quality check, assembly and alignment of DNA sequences were performed using Vector NTI Suite 6.0 (Informax Inc/ Invitrogen Life Technologies ${ }^{\mathrm{TM}}$ ). DNA sequences were aligned using CLUSTALW. The HKY+I evolutionary model on MODELTEST 3.7 was used to assess the phylogenetic relationships among the mitochondrial haplotypes. Analyses were based on the maximum likelihood and neighbor-joining methods using the programs PHYML and PAUP* 4.0b10, respectively. The haplotype diversity $(h)$ and the nucleotide diversity $(\pi)$ of haplotypes were calculated on DNAsp 4.5. Using Arlequin 3.11 , the genetic divergence between the P. corruscans populations in the Upper Paraná River and the Paraguay River basins were estimated by molecular $F_{\mathrm{ST}}$, and genetic variability portioning was tested by analysis of molecular variance.

\section{Results}

The amplified ISSR nuclear DNA fragments and the mtDNA sequences were analyzed in the $P$. corruscans and $P$. reticulatum populations and in the $2-\mathrm{PHybr} 1 \mathrm{spec}-$ imen. The ISSR analysis included the 28 most intense, well-defined and repeatable DNA fragments, which varied from $400 \mathrm{bp}$ to $2 \mathrm{~kb}$. Of those 28 loci, six (21.4\%) were monomorphic and exclusive to $P$. corruscans, and seven $(25 \%)$ were monomorphic and exclusive to $P$. reticulatum (Table 1).

Therefore, $46.4 \%$ of the analyzed ISSR fragments could be used to discriminate $P$. corruscans and $P$. reticulatum, clearly excluding the other species. This suggests that these ISSR fragments may be used as diagnostic molecular markers (Table 1). In addition, both species shared nine $(32.1 \%)$ monomorphic and two $(7.1 \%)$ polymorphic loci. There were two polymorphic loci exclusive to $P$. reticulatum, one locus was polymorphic in $P$. corruscans and monomorphic in $P$. reticulatum, and one locus was identified as monomorphic in $P$. corruscans and polymorphic in $P$. reticulatum. In the 2-PHybr 1 specimen, the ISSR primers amplified 22 DNA fragments, of which three fragments were exclusive to $P$. corruscans and five were exclusive to $P$. reticulatum (Table 1). An electrophoresis profile of fragments generated with the $(\text { GGAC) })_{3}$ T primer is illustrated in Figure 2.

The genetic differentiation pattern based on the Nei and $\mathrm{Li}$ genetic distance is illustrated by the dendrogram in Figure 3, and is complemented by the principal coordinates graph (Figure 4). The $P$. corruscans and $P$. reticulatum species were grouped in two distinct major clusters, which were clearly separated from each other. The 2-PHybr1 specimen displayed an intermediate position between the two species, with a small deviation toward the $P$. reticulatum side. The relative position of 2-PHybr1 to the $P$. reticulatum species indicates that this specimen contains a higher number of $P$. reticulatum ISSR fragments.

The intra-populational haplotype molecular diversity index, based on the average gene diversity over all haplotype loci, was estimated to be $0.0413( \pm 0.0312)$ for $P$. corruscans and $0.0726( \pm 0.0478)$ for $P$. reticulatum. Therefore, based on the ISSR markers, the P. corruscans population is genetically more homogenous than the $P$. reticulatum population. Several bootstrap values were higher than 0.5 in the $P$. reticulatum species, indicating a rate of polymorphism higher than that of $P$. corruscans (Figure 3). This was also evident in the principal coordinate analysis (Figure 4). The estimate of the haplotype molecular diversity index increased to $0.3269( \pm 0.1710)$ in the $P$. corruscans and $P$. reticulatum specimens when analyzed together as a group. The molecular fixation in$\operatorname{dex} F_{\mathrm{ST}}$, based on ISSR data, was estimated to be 0.9031 by comparing pairs of $P$. corruscans and $P$. reticulatum population samples. The Nei and Li genetic distance estimates, as expressed by the similarity complement, varied from zero to 0.51 at the individual level. Based on ISSR fragments, the Nei and Li genetic distance between $P$. corruscans and $P$. reticulatum populations was 0.3659 , a value that would be expected for distinct, yet closely related, species. The Nei and Li genetic distance was estimated to be 0.2195 between $P$. corruscans and the 2-PHybr1 specimen, and 0.1364 between $P$. reticulatum and 2-PHybr1. Therefore, numbers of the ISSR fragments derived from each of the Pseudoplatystoma species were unequal in the 2-Phybr1 specimen.

The amplified mtDNA fragment ( $470 \mathrm{bp})$ consisted of a partial sequence of the $t R N A^{T h r}$ gene, the complete sequence of the $t R N A^{\text {Pro }}$ gene, and $360 \mathrm{bp}$ comprising the hypervariable domain of the control region (GenBank accession numbers FJ024050 to FJ024079). The number 
Table 1. Approximate length in base pairs (bp) of ISSR fragments of $P$. corruscans, $P$. reticulatum and the hybrid specimen 2-PHybr1. The presence or absence of a DNA fragment in the agarose gel is indicated by + or - , respectively. The DNA fragment in a species can be monomorphic $(\mathrm{m})$ or polymorphic $(\mathrm{p})$.

\begin{tabular}{|c|c|c|c|c|c|c|c|c|c|c|c|}
\hline \multirow[b]{2}{*}{ Fragments ( bp) } & \multicolumn{11}{|c|}{ Primer $\left(\right.$ GGAC) ${ }_{4}$} \\
\hline & 2000 & 1800 & 1500 & 1100 & 800 & 780 & 700 & 650 & 600 & 550 & 450 \\
\hline P. corruscans & $+\mathrm{p}$ & - & $+\mathrm{p}$ & $+\mathrm{m}$ & $+\mathrm{m}$ & - & - & $+\mathrm{m}$ & - & $+\mathrm{m}$ & $+\mathrm{m}$ \\
\hline P. reticulatum & $+\mathrm{m}$ & $+\mathrm{p}$ & $+\mathrm{p}$ & $+\mathrm{m}$ & - & $+\mathrm{m}$ & $+\mathrm{m}$ & - & $+\mathrm{m}$ & $+\mathrm{m}$ & $+\mathrm{m}$ \\
\hline \multirow[t]{2}{*}{ Hybrid } & + & + & + & + & + & - & + & - & + & + & + \\
\hline & \multicolumn{11}{|c|}{ Primer $(\text { GGAC) })_{3} \mathrm{C}$} \\
\hline Fragments ( bp) & 1800 & 1500 & 1100 & 1000 & 900 & 800 & 600 & 500 & 450 & - & - \\
\hline P. corruscans & $+\mathrm{m}$ & $+\mathrm{p}$ & $+\mathrm{m}$ & $+\mathrm{m}$ & $+\mathrm{m}$ & $+\mathrm{m}$ & - & $+\mathrm{m}$ & $+\mathrm{m}$ & - & - \\
\hline P. reticulatum & $+\mathrm{p}$ & $+p$ & $+\mathrm{m}$ & - & $+\mathrm{m}$ & $+\mathrm{m}$ & $+\mathrm{m}$ & - & $+\mathrm{m}$ & - & - \\
\hline \multirow[t]{2}{*}{ Hybrid } & + & + & + & + & + & + & + & - & + & - & - \\
\hline & \multicolumn{11}{|c|}{ Primer $(\text { GGAC) })_{3} \mathbf{T}$} \\
\hline Fragments ( bp) & 2000 & 1700 & 1300 & 800 & 650 & 550 & 450 & 400 & - & - & - \\
\hline P. corruscans & - & - & $+\mathrm{m}$ & $+\mathrm{m}$ & - & $+\mathrm{m}$ & $+\mathrm{m}$ & - & - & - & - \\
\hline P. reticulatum & $+\mathrm{m}$ & $+\mathrm{m}$ & - & $+\mathrm{m}$ & $+\mathrm{m}$ & $+\mathrm{m}$ & - & $+\mathrm{m}$ & - & - & - \\
\hline Hybrid & + & - & - & + & + & + & + & - & - & - & - \\
\hline
\end{tabular}

\section{P. corruscans}

L N

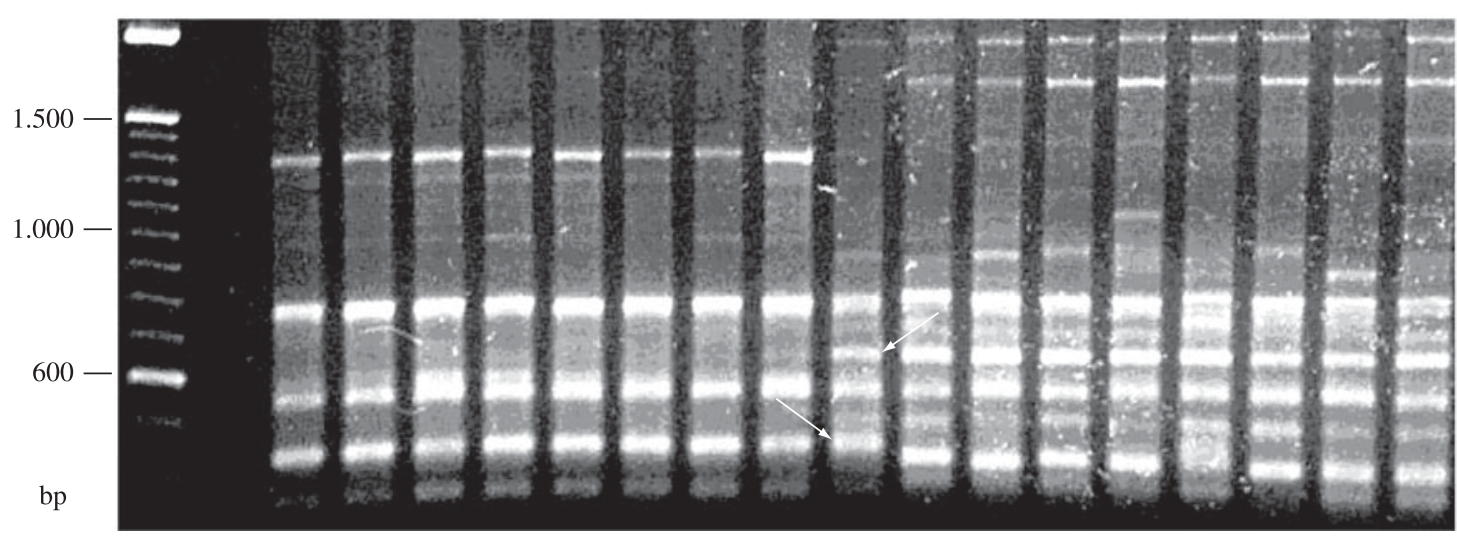

Figure 2. Electrophoresis profiles, obtained with the ISSR primer (GGAC) $)_{3}$, of $P$. corruscans and $P$. reticulatum from the northern Paraguay sub-basin. Lane H, $P$. reticulatum $\times P$. corruscans hybrid (2-PHybr1); Lane N, negative control without DNA; Lane L, molecular mass markers (Ladder $100 \mathrm{bp}$ ). Arrows indicate ISSR fragments exclusive to either $P$. corruscans (left) or $P$. reticulatum (right), which were inherited by the hybrid.

of nucleotide polymorphisms was low among the $t R N A$ sequences of $P$. corruscans and $P$. reticulatum. These sequences were therefore not informative and were not included in the analysis. The analyzed mitochondrial control region was rich in A-T nucleotides, which is typical of D-loop mtDNA sequences. The region consisted of: $\mathrm{T}=33.8, \mathrm{C}=17.7, \mathrm{~A}=36.5$ and $\mathrm{G}=11.9$. As shown in Table 2, the CLUSTALW alignment of the mtDNA hypervariable sequence of the control region revealed 41 polymorphic nucleotide sites, which were distributed in 16 haplotypes. The haplotypes were separated into two haplogroups. As is characteristic of the mtDNA control region, most changes were single nucleotide substitutions, with transitions being the most frequent type $(\mathrm{R}=\mathrm{si} / \mathrm{sv}=3.3)$. Of the 16 haplotypes identified, nine were from $P$. corruscans $(h=0.814 ; \pi=0.007)$ and seven were from $P$. reticulatum $(h=0.952 ; \pi=0.007)$. The two Pseudoplatystoma species were discriminated from each other by a total of 19 nucleotide sites. The mtDNA control region of the 2-PHybr-1 specimen was similar to that of the $P$. reticulatum species (Table 2). 


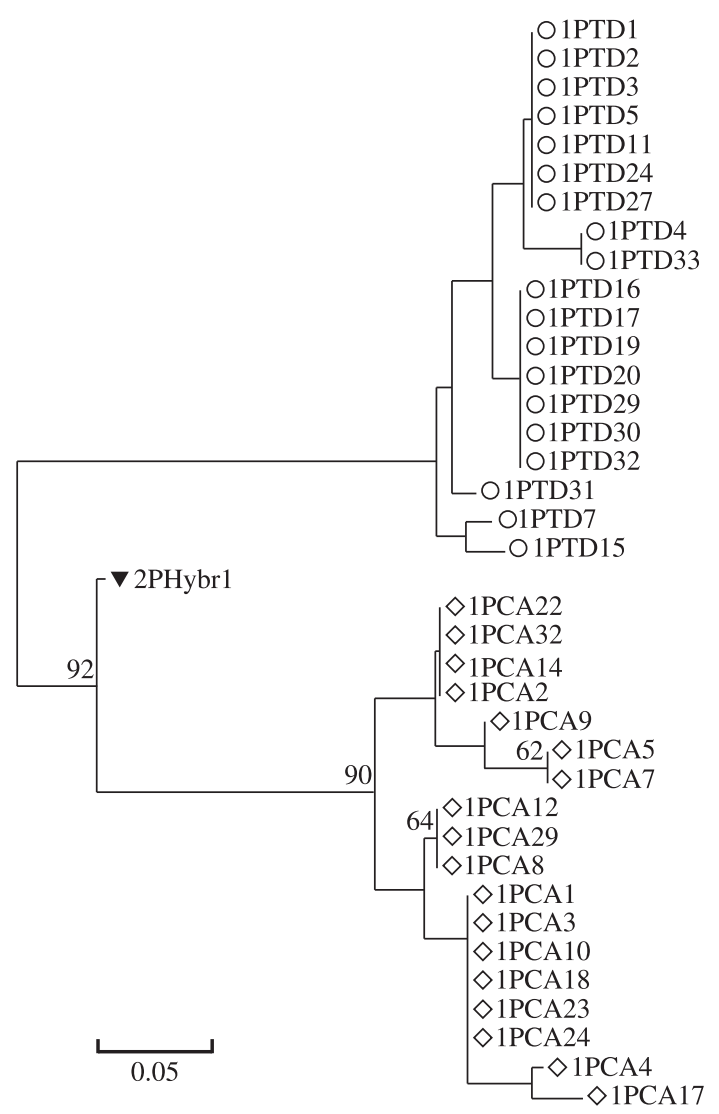

Figure 3. Neighbor-joining dendrogram based on Nei and Li similarity coefficients obtained from ISSR markers of Pseudoplatystoma: (O) P. corruscans and $(\diamond)$ $P$. reticulatum from the northern Paraguay Basin; $(\nabla)$ $P$. reticulatum $\times P$. corruscans hybrid captured in the Upper Paraná Basin. Numbers above branches are bootstrap values based on 1,000 replicates.

The genetic divergence between the two haplogroups was examined by phylogenetic analysis. Using the mod$\mathrm{el} \mathrm{HKY}+\mathrm{I}$ and the parameters Nst $=2$, TRatio $=5.3882$, Rates $=$ equal and Pinvar $=0.7345$, maximum likelihood and neighbor-joining trees were created (Figure 5). The two haplotype groups represented by $P$. corruscans and $P$. reticulatum were supported by a $100 \%$ bootstrap rate. The 2-PHybr1 haplotype was included in the $P$. reticulatum group. The intraspecific $\mathrm{HKY}+\mathrm{I}$ genetic distance was estimated to be 0.007 between the $P$. corruscans and $P$. reticulatum species. The interspecific distance was 0.085 , nearly eight times larger than the intraspecific distance.

\section{Discussion}

The genetic divergence between $P$. corruscans and $P$. reticulatum was estimated using ISSR and mtDNA polymorphisms. Monomorphic ISSR fragments exclusive to each species, consisting of $46.4 \%$ of the analyzed

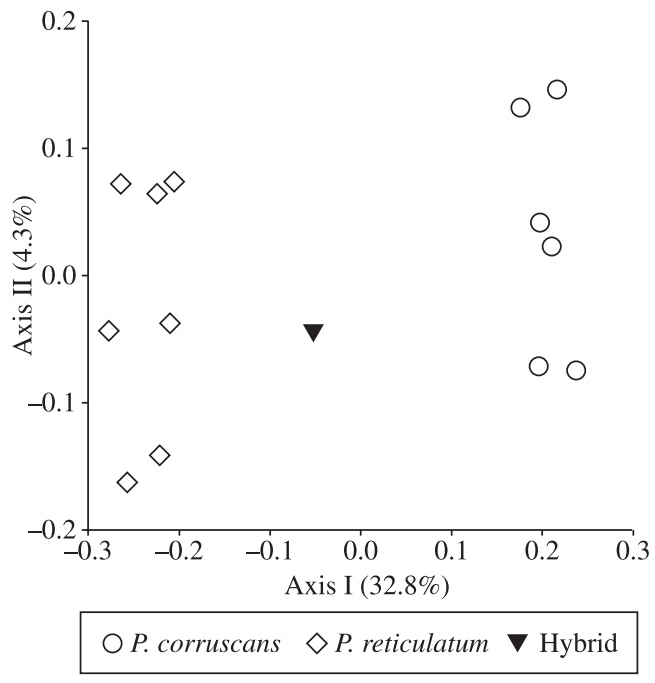

Figure 4. Dispersion in principal coordinates analysis (PCO) based on complements of Nei and Li similarity from ISSR markers of Pseudoplatystoma: (O) P. corruscans and $(\diamond)$ P. reticulatum from the northern Paraguay Basin; $(\nabla)$ $P$. reticulatum $\times P$. corruscans hybrid captured in the Upper Paraná Basin.

fragments, and 19 polymorphic nucleotide sites of the mtDNA control region clearly discriminated the two closely related $P$. corruscans and $P$. reticulatum species. These two species both have $2 \mathrm{n}=54$ chromosomes, but differences were detected in the nucleolar organizer regions (Porto-Foresti et al., 2007). The genetic parameters obtained with D-loop and ISSR indicate that the two Pseudoplatystoma species are genetically differentiated to an extent that seems consistent with distinct, yet closely related species. As the efficiency of the ISSR technique in the characterization of closely related fish species has been demonstrated, these results are accurate and reliable (Maltagliati et al., 2006).

The monomorphic and exclusive ISSR fragments could be used as molecular diagnostic markers capable of discriminating these two species. The ISSR data are in agreement with a previous study that identified many steady, monomorphic RAPD fragments exclusive to either $P$. corruscans or to $P$. reticulatum (Prioli et al., unpublished data). The genetic differentiation pattern demonstrated that $P$. corruscans and $P$. reticulatum have accumulated DNA polymorphisms in their nuclear and mitochondrial genomes, which were suitable for characterizing each species and useful as diagnostic DNA markers.

In contrast, because $P$. corruscans and $P$. reticulatum generate potentially fertile crossbreds in hatcheries, it is reasonable to assume that they must share a high degree of chromosomal (Porto-Foresti et al., 2007) and genomic similarities. Such genetic proximity between $P$. corruscans and $P$. reticulatum is evident as $32.1 \%$ of the monomorphic ISSR fragments were present in both species, $88.6 \%$ identity was found in the analyzed sequences of the differ- 


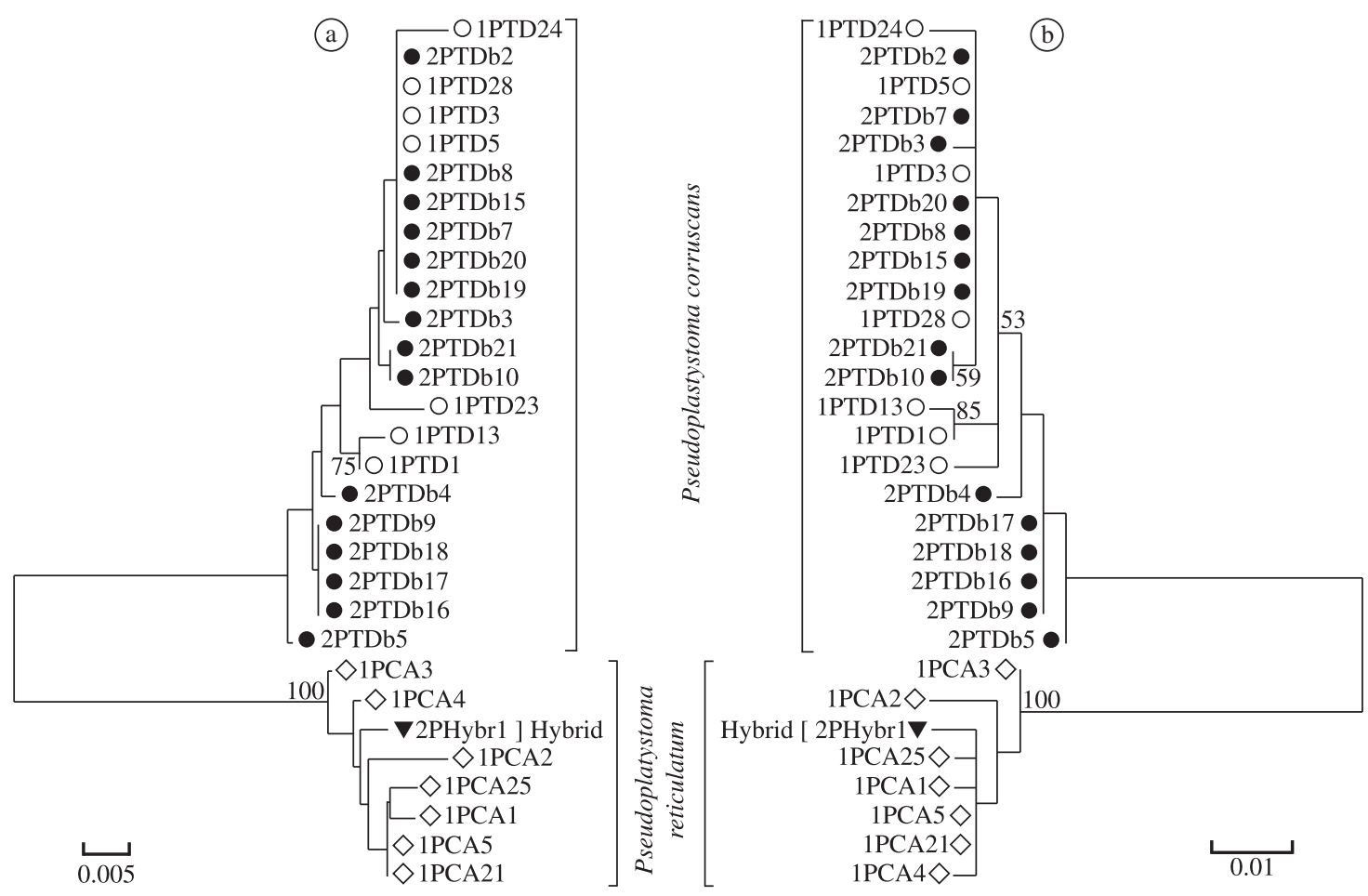

Figure 5. a) Neighbor-joining; and b) maximum likelihood dendrograms, obtained with the HKY + I model, from the hypervariable domain of the mtDNA control region (D-loop) haplotypes: (O) P. corruscans and $(\diamond)$ P. reticulatum from the northern Paraguay River sub-basin; (৩) P. corruscans from the Upper Paraná Basin; ( $)$ P. reticulatum $\times$ P. corruscans hybrid. Numbers above branches are bootstrap values based on 1,000 replicates.

ent mtDNA control regions and low nucleotide variation was observed in the tRNA sequences. In addition, NTS 5S rDNA markers are homogenous between these two species (Prioli et al., unpublished data).

The presence of both monomorphic ISSR fragments exclusive to $P$. corruscans or to $P$. reticulatum in the 2-PHybr1 specimen demonstrated that this individual is likely a hybrid between these two species. The data reject the possibility that the 2-PHybr1 specimen could be a hybrid between $P$. corruscans and another Amazonian Pseudoplatystoma species. Analysis of the 2-PHybr1 specimen shows that ISSR markers are also suitable for recognizing $P$. reticulatum $\times P$. corruscans hybrids.

The mtDNA data was unequivocal in demonstrating that the $P$. reticulatum species was the mother in the interspecific cross that generated the 2-PHybr1 specimen. Cytogenetic analysis was also shown to be useful for identifying $P$. reticulatum $\times P$. corruscans hybrids whose mothers were $P$. reticulatum (Porto-Foresti et al., 2007). In the present study, the unequal genetic distances between the 2-PHybr1 specimen and the parental species indicate that this hybrid is likely not a first generation descendent (Figures 2 and 3). This inference could be verified with further analysis of more ISSR markers.

The Pseudoplatystoma corruscans and P. reticulatum populations showed high values of haplotype diversity $(h)$ and low values of nucleotide diversity $(\pi)$. According to Grant and Bowen (1998), a combination of $h>0.5$ with $\pi<0.01$ indicates a recent reduction of the population followed by a demographic expansion. For reasons unknown, the $P$. corruscans and $P$. reticulatum species were apparently reduced to one or a few related haplotypes. Most likely, these two species independently survived a severe populational decline. Coronel et al. (2004) also found evidence of a reduction in a $P$. reticulatum (formerly $P$. fasciatum) population of the Bolivian Amazon region. Presently, the genetic integrity of the $P$. corruscans and $P$. reticulatum natural populations of the Paraná/Paraguay hydrographic basin could be endangered by reciprocal genetic introgression.

The 2-PHybr1 specimen was captured in the floodplain of the Upper Paraná River Basin (Luz et al., 2004). In the Cuiabá River Basin, where the two species occur in sympatry, a $P$. reticulatum $\times P$. corruscans hybrid was registered by Veríssimo et al. (2005). The occurrence of these hybrids in the Paraná and Manso rivers likely results from fishes escaping from farming stations. Accidental introduction of Pseudoplatystoma interspecific hybrids into a natural environment could be a threat to the genetic integrity of local populations due to the potential risk of backcrossing and subsequent gene introgression. This threat would be even more drastic in the Upper Paraná River Basin, where, due to geographic isolation, the $P$. reticulatum species does not exist naturally. 
Table 2. Nucleotide polymorphisms (41 sites) in the hypervariable sequence ( $360 \mathrm{bp})$ of the mtDNA control region (D-loop) in Pseudoplatystoma populations. Sampling locations (1 or 2) are indicated by the first number in each specimen identification: 1. Upper Paraná River Basin, 2. Paraguay River sub-basin. Haplotypes: Hapl-PTD = P. corruscans; Hapl-PCA $=P$. reticulatum. Entire sequences can be found at GenBank at accession numbers FJ024050 to FJ024079.

00111115788899999111111111112222333333333

Specimen Haplotypes Identification 34234581315715678012233356674779012233455

002556752315084843423035

\begin{tabular}{|c|c|c|c|}
\hline & & ans & А \\
\hline & & ans & $\ldots \ldots \ldots \ldots \ldots \ldots \ldots \ldots \ldots \ldots$ \\
\hline & & ans & $\ldots \ldots \ldots \ldots \ldots \ldots \ldots \ldots \ldots \ldots$ \\
\hline & & & $\ldots \ldots \ldots \ldots \ldots \ldots \ldots \ldots$ \\
\hline 1-PTI & & ans & $\ldots \ldots \ldots \ldots \ldots \ldots \ldots \ldots \ldots \ldots$ \\
\hline & & ans & $\cdots \cdots \cdots \cdots \cdots \cdots$ \\
\hline & & & $\ldots \ldots \ldots \ldots \ldots \ldots \ldots \ldots \ldots$ \\
\hline 0 & & ans & $\ldots \ldots \ldots \ldots \ldots \ldots \ldots \ldots \ldots \ldots \ldots$ \\
\hline $1-\mathrm{P}$ & & ans & $\cdots \cdots \cdots \cdots \cdots \cdots \cdots$ \\
\hline 列 & & & $\ldots \ldots$. . . . . . . . . . . \\
\hline J & & ans & $\ldots \ldots \ldots \ldots \ldots \ldots \ldots \ldots \ldots$ \\
\hline D & & ans & 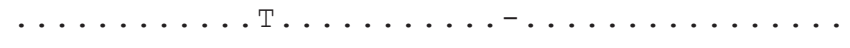 \\
\hline $1-$ & & ans & $\ldots \ldots \ldots \ldots \ldots \ldots \ldots$ \\
\hline P & & cans & $\ldots \ldots \ldots$. $\ldots \ldots \ldots$ G $\ldots$. . . . . . \\
\hline & & & 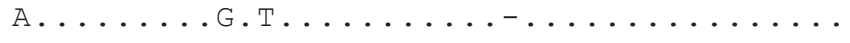 \\
\hline 3 & & & A.................. \\
\hline 1-PTDb4 & & ans & 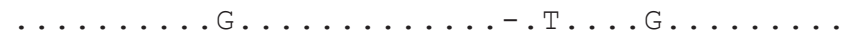 \\
\hline$-\mathrm{P}$ & $X$ & & 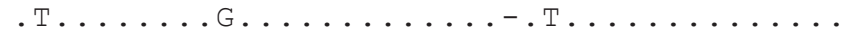 \\
\hline 1 & & &. $\mathrm{~T} \ldots \ldots$. $\ldots \ldots \ldots \ldots \ldots$. $\ldots \ldots \ldots$ \\
\hline 1-PTDl & & & 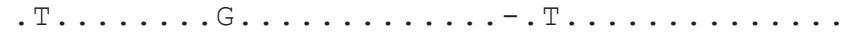 \\
\hline 1-PT & & & $\cdot T \ldots \ldots$............ \\
\hline $1-\mathrm{P}^{\prime}$ & & ins & 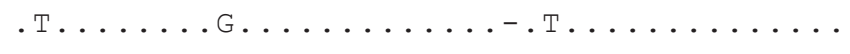 \\
\hline 1 & & & GC.GTTG.T.TT..GG..C.CTTGC \\
\hline $2-\mathrm{P}$ & & ılatum & PTGGTC..TTG.T.TT..GG..C.CTTGG \\
\hline 2-PCA5 & II & & ATCTATCG.CGTTTG.TC..TTG.T.TT..GG..C.СTTGG \\
\hline 2-PCA21 & II & & TG.TC..TTG.T.TT..GG..C.CTTGG \\
\hline 2-PCA4 & & & .TC..TTG.T.TT..GG... CTTGG \\
\hline 1-PHybr1 & & & G.T.G.TTG.T.TT..GG..C.CTTG \\
\hline 2-PCA2 & apl-PCA-VI & & ATCTATC..CGTTTG.TC..TTG.T.TT..GGAGCTCTTGG \\
\hline 2-PCA3 & Hapl-PCA-VII & P.reticulatum & АTCTATC..CGTTT..TC..TTG.T.TT..GG..C.CTTGG \\
\hline
\end{tabular}

The Canal da Piracema, a fish pass system recently built in the Itaipu Dam, could be allowing the introduction of $P$. reticulatum into the Upper Paraná River (Graça and Pavanelli, 2007; Makrakis et al., 2007), increasing the possibility of gene transfer between the two Pseudoplatystoma species. The free marketing of young $P$. reticulatum $\times P$. corruscans hybrids represents an additional genetic risk. If relatively large numbers of $P$. reticulatum and hybrid specimens reach the Upper Paraná River, the $P$. corruscans native population will be exposed to the risk of local extinction by genetic homogenization and replacement by a population of interspecific hybrids.
$P$. corruscans and $P$. reticulatum have accumulated ISSR and mtDNA nucleotide polymorphisms. These polymorphisms are sufficient for clearly discriminating the two species, for identifying a hybrid specimen captured in nature and as molecular diagnostic markers. These polymorphisms are therefore useful for genetic analysis, discrimination of these species and studies of threatened populations. Data presented herein improve the understanding of the genetic relatedness between the $P$. corruscans and $P$. reticulatum species. Furthermore, our results comprise potential tools for periodical evaluation of hybridization and genetic introgression or genetic homogenization, as well as for monitoring the genetic 
integrity of populations and programs of biological conservation.

Acknowledgements - The authors gratefully acknowledge A. A. Agostinho for valuable discussions and suggestions, C. S. Pavanelli and W. J. Graça for assisting with species identification, E. K. Okada for helping with fish sampling, and Nupelia-UEM for logistic support. Part of this research was supported by grants from CNPq-PELD (site 6) and Furnas Centrais Elétricas.

\section{References}

ABOIM, MA., MENEZES, GM., SCHLITT, T. and ROGERS, AD., 2005. Genetic structure and history of populations of the deep-sea fish Helicolenus dactylopterus (Delaroche, 1809) inferred from mtDNA sequence analysis. Molecular Ecology, vol. 14 , no. 5 , p. 1343-1354.

AVISE, JC., 2004. Molecular markers, natural history and evolution molecular markers. 2 ed. Sunderland: Sinauer Associates; Inc. Publishers. p. 475-540.

BUITRAGO-SUÁREZ, UA. and BURR, BM., 2007. Taxonomy of the catfish genus Pseudoplatystoma Bleeker (Siluriformes: Pimelodidae) with recognition of eight species. Zootaxa, vol. 1512, p. 1-38.

CORONEL, JS., MAES, GE., CLAUS, S., VAN DAMME, PA. and VOLCKAERT, FAM., 2004. Differential population history in the migratory catfishes Brachyplatystoma flavicans and Pseudoplatystoma fasciatum (Pimelodidae) from the Bolivian Amazon assessed with nuclear and mitochondrial DNA markers. Journal of Fish Biology, vol. 65, no. 3, p. 859-868.

GRAÇA, WJ. and PAVANELLI, CS., 2007. Peixes da planície de inundação do alto rio Paraná e áreas adjacentes. Maringá: Eduem. 241p.

GRANT, WS. and BOWEN, BW., 1998. Shallow population histories in deep evolutionary lineages of marine fishes: Insights from sardines and anchovies and lessons for conservation. Journal of Heredity, vol. 89, no. 5 p. 415-426.

GUPTA, M., CHYI, YS., ROMERO-SEVERSON, J. and OWEN, JL., 1994. Amplification of DNA markers from evolutionary diverse genomes using single primers of simplesequence repeats. Theoretical and Applied Genetics, vol. 89, no. 8, p. $998-1006$.

LUZ, KDG., OLIVEIRA, EF., PETRY, AC., JÚLIO Jr., HF., PAVANELLI, CS. and GOMES, LC., 2004. Fish assemblages in the Upper Paraná River Floodplain. In AGOSTINHO, AA., RODRIGUES, L., GOMES, LC., THOMAZ, SM. and MIRANDA, LE. (Eds.). Strutcture and functioning of the Paraná River and its floodplain. Maringá: Eduem. 275p.
MAKRAKIS, S., GOMES, LC., MAKRAKIS, MC., FERNANDEZ, DR., PAVANELLI, CS., 2007. The Canal da Piracema at Itaipu Dam as a fish pass system. Neotropical Ichthyology, vol. 5, no. 2, p. 185-195.

MALTAGLIATI, F., LAI, T., CASU, M., VALDESALICI, S. and CASTELLI, A., 2006. Identification of endangered Mediterranean cyprinodontiform fish by means of DNA intersimple sequence repeats (ISSRs). Biochemical Systematics and Ecology, vol. 34, no. 8, p. 626-634.

OLIVEIRA, AV., PRIOLI, AJ., PRIOLI, SMAP., BIGNOTTO, TS., JÚlIO Jr., HF., CARRER, H., AGOSTINHO, CS. and PRIOLI, LM., 2006. Genetic diversity of invasive and native Cichla (Pisces: Perciformes) populations in Brazil with evidence of interspecific hybridization. Journal of Fish Biology, vol. 69, Suppl. B, p. 260-277.

PETRERE-Jr., M., AGOSTINHO, AA., OKADA, EK. and JÚLIO Jr., HF., 2002 Review of the Fisheries in the Brazilian Portion of the Paraná/Pantanal Basin. In COWX, IG. (Ed.). Management and ecology of lake and reservoir fisheries. London: Fishing New Book. p. 123-143.

PORTO-FORESTI, F., NUNES, T., BORTOLOZZI, J., SENHORINI, JA., OLIVEIRA, C. and FORESTI, F., 2007. Identification of cytogenetic markers in Pseudoplatystoma fasciatum (cachara), Pseudoplatystoma corruscans (pintado), and their hybrids "cachapinta" and "pintachara" used in aquaculture programs. Aquaculture, vol. 272, Suppl. 1, p. S301-S302.

PRIOLI, SMAP., PRIOLI, AJ., JÚLIO Jr., HF., PAVANELLI, CS., OLIVEIRA, AV., CARRER, H., CARRARO, DM. and PRIOLI, LM., 2002. Identification of Astyanax altiparanae (Teleostei, Characidae) in the Iguaçu River, Brazil, based on mitochondrial DNA and RAPD markers. Genetics and Molecular Biology, vol. 25, no. 4, p. 421-430.

REDDY, MP., SARLA, N. and SIDDIQ, EA., 2002. Inter simple sequence repeat (ISSR) polymorphism and its application in plant breeding. Euphytica, vol. 128, no. 1, p. 9-17.

SATO, Y., CARDOSO, EL., SALLUM, WB. and GODINHO, HP., 1997. Indução experimental da desova do surubim Pseudopatystoma corruscans. In MIRANDA, MOT. (Org.). Surubim. Belo Horizonte: IBAMA. p. 69-79. Coleção Meio Ambiente, Série Estudos Pesca.

VERÍSSIMO, S., PAVANELLI, CS., BRITSKI, HA. and MOREIRA, MMM., 2005. Fish, Manso Reservoir region of influence, Rio Paraguay basin, Mato Grosso State, Brazil. Check List, vol. 1, no. 1, p. 1-9.

WHITMORE, DH., THAI, TH. and CRAFT, CM., 1992. Gene amplification permits minimally invasive analysis of fish mitochondrial DNA. Transactions of the American Fisheries Society, vol. 121, no. 2, p. 170-177. 